\title{
Venturia inaequalis resistance in local Spanish cider apple germplasm under controlled and field conditions
}

\author{
Alejandro Martínez-Bilbao • Amaya Ortiz-Barredo • \\ Emilio Montesinos $\cdot$ Jesús Murillo
}

Received: 22 November 2011/Accepted: 17 May 2012/Published online: 16 June 2012

(C) The Author(s) 2012. This article is published with open access at Springerlink.com

\begin{abstract}
Host resistance is a key method for the integrated management of apple scab caused by Venturia inaequalis, which is one of the most important diseases of apple. Artificial inoculation of 92 cider apple cultivars with a mixed inoculum of $V$. inaequalis identified 19 weakly resistant and 19 resistant cultivars. Twelve of these resistant cultivars were previously classified as having low susceptibility to fire blight, and four of them showed complete or weak resistance to races $(1),(1,6)$ and $(6,7,13)$ of $V$. inaequalis. The analysis of a selection of 72 cultivars for 6 years under field conditions identified 14 cultivars that were classified as resistant to apple scab under high disease pressure involving one to six Mills
\end{abstract}

Electronic supplementary material The online version of this article (doi:10.1007/s10681-012-0723-z) contains supplementary material, which is available to authorized users.

A. Martínez-Bilbao · A. Ortiz-Barredo · J. Murillo ( $\square$ ) Laboratorio de Patología Vegetal, Departamento de Producción Agraria, Escuela Técnica Superior de Ingenieros Agrónomos, Universidad Pública de Navarra, 31006 Pamplona, Spain

e-mail: jesus.murillo@unavarra.es

A. Ortiz-Barredo

NEIKER-Tecnalia, Centro de Arkaute, Apdo. 46, 01080 Vitoria, Spain

\section{E. Montesinos}

Instituto de Tecnología Agroalimentaria-XaRTACIDSAV, Universidad de Girona, Av. Lluís Santaló s/n, 17071 Gerona, Spain periods of severe risk of infection each year. Eight out of these 14 cultivars previously showed high levels of resistance to fire blight, which would allow the incorporation of genetic resistance in the integrated production of cider apples in Spain through their use in breeding programs.

Keywords Apple scab · Fire blight .

Erwinia amylovora $\cdot$ Virulence $\cdot$ Resistance genes

\section{Introduction}

Apple scab, caused by the fungus Venturia inaequalis, is considered the most damaging disease of apple in economic terms (MacHardy 1996). Control of the disease relies heavily on the use of fungicides because the majority of the commercial apple cultivars are highly susceptible to apple scab, although this strategy readily promotes the selection of strains of the pathogen resistant to fungicides. In particular, the benzimidazoles and inhibitors of the biosynthesis of ergosterol (IBE) have been intensively used in the past. The first cases of resistance to benzimidazoles were detected in those countries where these fungicides were most intensively used, and various resistant strains to IBE were found several years ago in France and other European countries (Schnabel and Parisi 1997), and later in commercial apple orchards in Indiana, USA (Quello et al. 2010). Also, V. inaequalis strains resistant to sterol demethylation inhibitors were isolated already nearly a decade ago (Schnabel 
and Jones 2001; Koller et al. 2004; Ma and Michailides 2005). In spite of that, control of apple scab in many countries still relies heavily on the use of these fungicides. Nevertheless, efforts are devoted worldwide to the implementation of complementary and alternative control methods, and especially the use of apple cultivars with partial or complete resistance to the pathogen (Gessler et al. 2006; Brun et al. 2008).

Malus floribunda 821 has traditionally been the main source of resistance genes used in apple breeding programmes (MacHardy 1996; Bénaouf and Parisi 2000). Initially, this resistance was attributed to the Rvi6 (previously $V f$ or HcrVf2) gene, but has since been demonstrated to be of a more complex nature (Hough et al. 1953, 1970; Bénaouf and Parisi 2000; Bus et al. 2011). Nearly a century after the initiation of breeding programs to introduce scab resistance to apple, none of the several cultivars developed to date has had a major impact in the market and did not result in the displacement of the major susceptible cultivars (MacHardy 1996). Therefore, efforts to obtain commercially viable apple cultivars with durable resistance(s) remain a major target for breeding programmes (Hartman et al. 2000; Bowen et al. 2011). To date, 17 gene-for-gene relationships between $V$. inaequalis and apple species have been identified (Bowen et al. 2011; Bus et al. 2011). Race (6) isolates, which overcome the resistance conferred by Rvi6, have been detected in different places in Europe, including the North of Spain (Parisi et al. 2004; Martínez-Bilbao and Murillo 2005). Indeed, most Rvi6 apple cultivars grown commercially are highly susceptible to scab. This situation highlights the need to search for cultivars that contain new resistance genes for their direct implementation in crops or their inclusion in future breeding programs (Fischer and Dunemann 2000; Lespinasse et al. 2000). Likewise, there is a growing interest in the characterization of local apple varieties in order to preserve biodiversity and to search for agronomic and adaptive traits for production or breeding programs, such as better adaptation to local conditions and resistance to pathogens (Cavanna et al. 2008; Tiirmaa et al. 2009; Lacis et al. 2011; Rop et al. 2011). This is particularly important for non-sparkling apple cider production in Spain, which is based on the use of local cultivars and where the use of plant resistance can contribute to organic production systems (Lizar et al. 2008).
A collection of more than 250 cider and table apple cultivars originating from Northern Spain has been established and is being characterized (Lizar 1996; Itoiz and Royo 2003; Pereira-Lorenzo et al. 2007; Lizar et al. 2008). Previously, we evaluated part of this collection for resistance to fire blight (Erwinia amylovora) leading to the identification of 48 cultivars with high levels of resistance to this disease (MartínezBilbao et al. 2009). Here we undertook the evaluation of the susceptibility to $V$. inaequalis of a selection of 92 apple cultivars, which included all of those with high resistance to E. amylovora, both in artificial inoculation experiments and in field conditions over a 6 years period.

\section{Materials and methods}

Plant material

Starting in year 2000, susceptibility to $V$. inaequalis was evaluated in 92 apple cultivars native from Spain, most of which originate from the Navarre and Basque Country counties. Forty-eight of them were selected because of their low susceptibility to fire blight (E. amylovora) (Martínez-Bilbao et al. 2009) whereas the remaining 44 were of interest to the local cider growers due to their pomological characteristics (Lizar personal communication, 1996). These cultivars were collected by the Instituto Técnico de Gestión Agrícola (ITGA, Navarre, Spain) (Lizar 1996) and are included in the germplasm collection of the Universidad Pública de Navarra (Lizar et al. 2008). Seventytwo of these cultivars were planted in an experimental orchard to evaluate their response to diseases in natural conditions. Five to six repetitions per cultivar were distributed randomly in the orchard, which was laid out in six rows of 63 trees. The experimental orchard is located in Santesteban, in the Northern wet area of Navarre. No bactericides or fungicides were used during the assay period, and insecticides were only occasionally applied. Plants of cv. Royal Gala were used as susceptible controls in all inoculation experiments. In all cases, commercial and local cultivars were grafted on M9 rootstock towards the end of August and kept in $2 \mathrm{~L}$ pots in the field until the following spring, when they were inoculated or transplanted into the Santesteban experimental orchard. 
Preparation of inocula and plant inoculation

Initial evaluation of susceptibility to scab was done using a mixed conidial inoculum as described by Parisi et al. (1993). In order to increase the pathogenic variability, the inoculum was prepared from naturally infected samples collected in 1999 from several places and cultivars in Spain: Añorga (several local cultivars), Fraisoro (cv. Golden Delicious), Goierri (cv. Reineta Roja and local cider apples), Hernani (cv. Golden Delicious) and Zubieta (local cider apples), all in Guipúzcoa; Gerona (cvs. Cardinale, Cox's Orange Pippin and Reineta de Aragón), and Cizur Mayor, Navarre (cvs. Reineta Gris, Reineta Blanca and Royal Gala). Leaves collected from trees showing fresh scab lesions were dried for 1 day at room temperature and preserved at $-20{ }^{\circ} \mathrm{C}$ until inoculum was prepared essentially as described by Parisi et al. (1993). Briefly, clearly sporulating lesions were collected with a $1 \mathrm{~cm}$ diameter cork borer and leaf disks were gently shaken for $30 \mathrm{~min}$ in sterile distilled water containing $1 \mu \mathrm{L} \mathrm{mL} \mathrm{L}^{-1}$ of Tween 20 . The suspension was then adjusted to $2.5 \times 10^{5}$ conidia $\mathrm{mL}^{-1}$, resulting in inoculum UPNA99, which was stored at $-20{ }^{\circ} \mathrm{C}$ until used. To minimize loss of virulence, inoculum UPNA99 was rejuvenated and bulked up before each inoculation on apple plantlets grown from seed from open-pollinated cv. Royal Gala as described by Szkolnik (1986).

To evaluate the resistance to selected races, we used axenic inocula of monoconidial reference strains 104 , 302 and 1066, corresponding to races $(1),(1,6)$ and $(6$, 7, 13), respectively (Bénaouf and Parisi 2000; Bus et al. 2011). These strains were routinely propagated on potato dextrose agar (Oxoid, Basingstoke, UK) and conidial suspensions for inoculations were prepared in vitro (Keitt and Palmiter 1938; Roberts and Crute 1994), adjusted to $2.5 \times 10^{5}$ conidia $\mathrm{mL}^{-1}$ and stored at $-20{ }^{\circ} \mathrm{C}$ until used.

Towards the end of March or beginning of April, and 3 weeks before their inoculation, plantlets were transferred to a greenhouse equipped with anti-insect screens and temperature control, ensuring that the temperature was never below $12{ }^{\circ} \mathrm{C}$ or above $30^{\circ} \mathrm{C}$ during the assays. Inoculations were done as described (Parisi et al. 1993) using the youngest shoots of plantlets with seven to eleven unfolded leaves and three to six plantlets per cultivar. Briefly, conidial suspensions were sprayed onto leaves using an airbrush (model VL, Paasche Airbrush) from a distance of about $15 \mathrm{~cm}$ until they were uniformly coated with droplets, without runoff, and plantlets were then covered with a clear polyethylene bag for $48 \mathrm{~h}$. After this period, the bags were removed and the plantlets were maintained in the greenhouse until symptom assessment. When using an axenic inoculum, and to avoid inoculum dispersion, plants were maintained in a growth chamber under a 16/8 h light/ dark photoperiod at $18{ }^{\circ} \mathrm{C}$ and $80 \%$ relative humidity. Three to six plantlets were assayed per cultivar, and one to three actively growing $20-30 \mathrm{~cm}$ long shoots per plant were inoculated in 2000 and 2001.

\section{Symptom assessment}

Scab occurrence on artificially inoculated young shoots was assessed 21 days after inoculation using a scale divided into six classes (Chevalier et al. 1991): class $0=$ no symptom; class $1=$ hypersensitivity (pinpoint pits); class $2=$ resistance, chlorosis, either together or separate, without sporulation; class $3 \mathrm{a}=$ weak resistance, chlorosis, and necrosis, either together or separate, with slight sporulation; class $3 \mathrm{~b}=$ weak susceptibility, chlorosis, and necrosis, either together or separate, with sporulation; and class 4 = susceptibility, abundant sporulation without chlorosis and necrosis, either together or separate (Supplementary Fig. 1). Only cultivars in classes 0,1 and 2 were considered as resistant. Cultivars were classified according to the maximum class of symptoms among all the inoculated shoots as described previously (Parisi et al. 1993; Roberts and Crute 1994; Bénaouf and Parisi 2000; Fischer and Dunemann 2000; Bus et al. 2005). Additionally, 21 days after inoculation we also computed the median and confidence limits $(\alpha=0.05)$ for the symptoms values (Belfanti et al. 2004) in order to describe the overall response of each cultivar (Supplementary Table 1). Severity (percentage of leaf area with sporulating symptoms), incidence (percentage of scabbed leaves) and sporulation, were evaluated as described by Parisi et al. (1993). The leaf area covered by sporulating lesions was estimated using image analysis software (WINDIAS Delta-T, UK).

The assessment of scab occurrence in the experimental orchard was carried out approximately every 2 months from March to October in 2002-2007. The presence of scab lesions and sporulation was assessed on leaves and fruits in every tree of the orchard, as well 
Table 1 Distribution of 92 local apple cultivars into different classes of susceptibility to apple scab and fire blight in glasshouse assessments

\begin{tabular}{lllll}
\hline Susceptibility to apple scab & \multicolumn{2}{l}{ Susceptibility to fire blight } \\
\cline { 2 - 4 } & Low susceptibility & Moderate susceptibility & High susceptibility & Total \\
\hline Resistance (0-2) & 12 & 4 & 3 & 19 \\
Weak resistance (3a) & 10 & 6 & 3 & 19 \\
Weak susceptibility (3b) & 13 & 8 & 8 & 29 \\
Susceptibility (4) & 13 & 6 & 6 & 20 \\
Total & 48 & 24 & 92 \\
\hline
\end{tabular}

a Susceptibility to the mixed inoculum UPNA99, using the scale of Chevalier et al. (1991)

b Susceptibility to fire blight was previously evaluated by artificial inoculation of young shoots (Martínez-Bilbao et al. 2009)

as defoliation, using an exponential type $0-5$ severity scale comprising nine levels (Lateur and Populer 1994). The cultivars were classified into four arbitrary susceptibility categories: resistance $(0-<1)$, weak resistance $(1-<2.5)$, weak susceptibility $(2.5-<4)$ and susceptibility (4-5) (Lateur and Populer 1994). Since the development of scab infections is highly dependent on climatic conditions, we calculated the occurrence of periods of light, moderate and severe risk of infection based on potential infection periods determined by hours of leaf wetness at various temperatures (Mills and LaPlante 1951; MacHardy and Gadoury 1989). Meteorological information was obtained from the Spanish governmental meteorology office (Agencia Estatal de Meteorología, Ministerio de Agricultura, Alimentación y Medio Ambiente) and from a dedicated weather station (model Vaisala HMP45A) located in the experimental orchard.

\section{Analysis of leaf infection}

The average number of hyphae per infection site and their accumulated length was estimated microscopically (Nicholson et al. 1972; Ortega et al. 1998). Briefly, leaf discs were sampled from inoculated apple plantlets using a $1 \mathrm{~cm}$ diameter cork borer, cleared in boiling ethanol and stained with $0.05 \%$ toluidine blue for $10 \mathrm{~min}$ before mounting them on glass slides for examination under a phase contrast microscope. Five leaf discs and twenty infection sites per disc were evaluated for each combination of cultivar and inoculum.

Race determination

The presence of races (1)-(7) and complex races of $V$. inaequalis in inoculum UPNA99 was determined by inoculation on the differential apple clones TSR34T15, Geneva, TSR33T239, 9-AR2T196, Prima, and Malus $\times$ floribunda 821 (Parisi et al. 1993; Bénaouf and Parisi 2000), all obtained from E. Dapena (Servicio Regional de Investigación Agroalimentaria, Asturias), as well as the universal susceptible cv. Royal Gala, as described above. Symptoms were assessed 21 days after inoculation using the Chevalier Index (Chevalier et al. 1991), as described above.

\section{PCR analyses}

The presence of resistance gene Rvi6 (Vinatzer et al. 2001) in local cultivars that showed high resistance to apple scab and fire blight (cultivars 1.1.9, 1.1.20, 2.1.1, 2.1.14, 2.1.21, 3.1.50, 3.1.75, 3.1.80, 3.1.87, 3.1.100, $5.1 .23,5.1 .66)$ was investigated by PCR amplification using the Rvi6-specific primers T1-For (5'-CAATGCCTTACGTGGTGAAA- $\left.3^{\prime}\right)$ and RT2-Rev ( $5^{\prime}$ CAGGGATTCCAGCCAATCTA- ${ }^{\prime}$ ) at a final concentration of $0.8 \mu \mathrm{M}$. The PCR reactions contained $50 \mathrm{ng}$ of purified plant genomic DNA (Lodhi et al. 1994) and consisted of one cycle of $10 \mathrm{~min}$ at $94{ }^{\circ} \mathrm{C}$, followed by 35 cycles of $94{ }^{\circ} \mathrm{C}$ for $1 \mathrm{~min}, 58{ }^{\circ} \mathrm{C}$ for $1 \mathrm{~min}$ and $72{ }^{\circ} \mathrm{C}$ for $2 \mathrm{~min}$, finishing with a cycle of $10 \mathrm{~min}$ at $72{ }^{\circ} \mathrm{C}$.

\section{Results}

Scab susceptibility of local cider apple cultivars

We evaluated 92 apple cultivars from the germplasm collection with the mixed inoculum UPNA99 (Table 1; Supplementary Table 1). Thirty-eight of the cultivars were classified as either resistant (19 cvs.) or weakly 
Table 2 Correspondence between the classes of susceptibility to apple scab (Chevalier et al. 1991) and ranges of severity, incidence and degree of sporulation on leaves

\begin{tabular}{llll}
\hline Susceptibility $^{\mathrm{a}}$ & Severity $^{\mathrm{b}}$ & $\begin{array}{l}\text { Incidence }^{\mathrm{c}} \\
(\%)\end{array}$ & Sporulation $^{\mathrm{d}}$ \\
\hline Resistance & 0 & 0 & 0 \\
Weak resistance & 0 & 0 & $0.2-2.7 \times 10^{3}$ \\
Weak & $1-2$ & $22.2-100$ & $0.4-4.6 \times 10^{4}$ \\
$\quad$ susceptibility & & $45.7-100$ & $1.2-6.6 \times 10^{6}$ \\
Susceptibility & $3-4$ & 4
\end{tabular}

${ }^{a}$ As determined following susceptibility grading into six different classes (Chevalier et al. 1991)

b Infection severity values were assessed on the following grading scale (Parisi et al. 1993): 1 indicates a percentage of leaf area with sporulating symptoms from 0 to $1 \% ; 2$, from 1 to $5 \%$; 3 , from 5 to $10 \%$; 4 , from 10 to $25 \%$; 5 , from 25 to $50 \%$; 6 , from 50 to $75 \%$; and 7 , from 75 to $100 \%$. Severity was estimated in 56 apple cultivars

c Percentage of leaves with sporulating lesions. Incidence was estimated for all the 92 inoculated apple cultivars

d Number of conidia per $\mathrm{cm}^{2}$ of foliar area, estimated in 33 apple cultivars

resistant (19 cvs.) to the inoculum. From the remaining ones, 29 showed weak susceptibility, whereas 25 cultivars were susceptible.

Severity, incidence and sporulation in inoculated cultivars

We evaluated the progression and multiplication of $V$. inaequalis in selected inoculated apple cultivars in order to confirm the validity of our macroscopic assessment of susceptibility (Table 2). As described previously (Chevalier and Lespinasse 1991; Chevalier et al. 1991; MacHardy 1996), severity (percentage of leaf area with sporulating symptoms), incidence (percentage of scabbed leaves) and sporulation were always zero for those cultivars classified as resistant. However, we detected a slight sporulation in the weakly resistant cultivars that was only observed microscopically. Likewise, we observed significant levels of severity, incidence and sporulation in the cultivars classified in the weak susceptibility or susceptibility classes. Collectively, these results indicate that our macroscopic assessment of susceptibility is correlated with the successful colonization of the host tissues by the pathogen.
Table 3 Degree of resistance to reference race (1) isolate 104, race $(1,6)$ isolate 302 and race $(6,7,13)$ isolate 1,066 of $V$. inaequalis of 12 apple cultivars showing resistance to the UPNA99 scab inoculum and low susceptibility to fire blight

\begin{tabular}{llll}
\hline Cultivar & \multicolumn{3}{l}{ V. inaequalis isolate } \\
\cline { 2 - 4 } & 104 & 302 & 1066 \\
\hline 1.1 .9 & $\mathrm{WR}^{\mathrm{a}}$ & $\mathrm{S}$ & $\mathrm{WS}$ \\
1.1 .20 & $\mathrm{WR}$ & $\mathrm{R}$ & $\mathrm{WR}$ \\
2.1 .1 & $\mathrm{R}$ & $\mathrm{S}$ & $\mathrm{S}$ \\
2.1 .14 & $\mathrm{R}$ & $\mathrm{R}$ & $\mathrm{S}$ \\
2.1 .21 & $\mathrm{WR}$ & $\mathrm{WS}$ & $\mathrm{WR}$ \\
3.1 .50 & $\mathrm{R}$ & $\mathrm{R}$ & $\mathrm{WR}$ \\
3.1 .75 & $\mathrm{WR}$ & $\mathrm{R}$ & $\mathrm{R}$ \\
3.1 .80 & $\mathrm{WR}$ & $\mathrm{S}$ & $\mathrm{R}$ \\
3.1 .87 & $\mathrm{R}$ & $\mathrm{S}$ & $\mathrm{WR}$ \\
3.1 .100 & $\mathrm{R}$ & $\mathrm{R}$ & $\mathrm{WR}$ \\
5.1 .23 & $\mathrm{R}$ & $\mathrm{R}$ & $\mathrm{S}$ \\
5.1 .66 & $\mathrm{R}$ & $\mathrm{S}$ & $\mathrm{R}$ \\
Royal Gala & $\mathrm{S}$ & $\mathrm{S}$ & $\mathrm{S}$ \\
\hline
\end{tabular}

The susceptibility of these apple cultivars to fire blight was as previously reported (Martínez-Bilbao et al. 2009); Royal Gala was used as susceptible control for apple scab and fire blight

${ }^{\text {a }} R$ resistance, $W R$ weak resistance, WS weak susceptibility, $S$ susceptibility (Chevalier et al. 1991)

Resistance of selected local cultivars to races (1), (6) and (7) of $V$. inaequalis

The mixed inoculum UPNA99 contained, at least, races (0), (2) and (6) of $V$. inaequalis, because it elicited typical disease symptoms with abundant sporulation $\left(>10^{6}\right.$ conidia $\left.\mathrm{cm}^{-2}\right)$ on clones TSR34T15 (susceptible to race (2)) and Prima (susceptible to race (6)). This inoculum contained race ( 0 ) because conidia from leaves collected in Girona elicited disease only on cv. Royal Gala (Martínez-Bilbao and Murillo 2005).

Twelve local cultivars that were previously classified as having low susceptibility to fire blight (Martínez-Bilbao et al. 2009) were also resistant to apple scab upon inoculation with a mixed inoculum (Table 1). In order to better characterize these cultivars, we evaluated their resistance to monoconidial isolates 104, 302 and 1066 of $V$. inaequalis corresponding to races $(1),(1,6)$ and $(6,7,13)$, respectively (Table 3). All of the cultivars showed either complete or weak resistance to race (1), whereas there were variable responses to the races $(1,6)$ and $(6,7,13)$ 
isolates (Table 3). Four of the cultivars (1.1.20, 3.1.50, 3.1.75 and 3.1.100) showed complete or weak resistance to the three isolates, of which 3.1 .75 is of considerable interest in that it shows resistance to both races $(1,6)$ and $(6,7,13)$ isolates. Additionally, cultivars 3.1 .80 and 5.1.66 were the only other ones that showed resistance to the race $(6,7,13)$ isolate.

As it occurred previously upon inoculation with the mixed inoculum (Table 2), values of severity in the grading scale (Parisi et al. 1993) were zero for the resistance/weak resistance interactions and 1-2 and 3-4, respectively, for the weak susceptibility/susceptibility interactions. Additionally, the incidence was $0 \%$ for the resistance/weak resistance interactions and 22.2-100 and 45.7-100\%, respectively, for weak susceptibility/susceptibility. Likewise, we did not detect sporulation on resistant interactions and only a low level of sporulation $\left(0.2-2.7 \times 10^{3}\right.$ conidia $\mathrm{cm}^{-2}$ leaf area) on cultivars classified as weakly resistant. By contrast, and as expected, we observed profuse sporulation of $0.4-4.6 \times 10^{4}$ and $1.2-6.6 \times 10^{6}$ conidia $\mathrm{cm}^{-2}$ leaf area for the weakly susceptible and susceptible interactions, respectively.

Microscopic observation of leaf tissues from interactions leading to resistance or weak resistance confirmed that conidia germinated and penetrated the leaf host tissues, forming a primary stroma and a few runner hyphae before their growth was halted. Indeed, even 21 days after inoculation the average number of runner hyphae was 1.6 to 3.3 per infection site, with an average accumulated length of 0.14-0.27 mm (data not shown). Conversely, the weakly susceptible and susceptible interactions were characterized by the unrestricted growth of the pathogen, resulting in the presence of abundant stroma and mycelium, with numerous conidiophores.

The selected cultivars do not appear to contain the $R v i 6$ resistance gene

Some of the local cultivars showed differential interactions with the reference races $(1),(1,6)$ and $(6,7,13)$ (Table 3), hence we determined whether they contained Rvi6 by amplification of a marker for gene HcrVf2 (Vinatzer et al. 2001; Belfanti et al. 2004). Gene HcrVf2 is one of the three paralogs found in the Rvi6 ( $V f$ ) cluster, and the responsible for the Rvi6 resistance phenotype. PCR amplification using primers RT1-for y RT2-rev, specific for gene HcrVf2 (Vinatzer et al. 2001), repetitively produced the expected $855 \mathrm{nt}$ amplicon with the positive control (cv. Prima), but no amplification bands for the local cultivars Erremedio (1.1.9), 2.1.1, 2.1.14, 3.1.50, 3.1.100 and 5.1.23 suggesting that they do not contain gene HcrVf2.

Field evaluation of resistance to apple scab in selected cultivars

In order to obtain a more direct estimation, we assessed the resistance to apple scab of a selection of 72 apple cultivars in field conditions. This selection included 66 of the cultivars evaluated in the glasshouse for apple scab resistance, among which were the 12 cultivars that showed low susceptibility to E. amylovora and resistance to inoculum UPNA99 (Supplementary Table 1), except cultivars 3.1.87 and 5.1.66. We observed the occurrence of apple scab in every year of the experiment (Table 4; Supplementary Table 1). The number of cultivars classified as

Table 4 Classification of 72 apple cultivars according to the development of apple scab symptoms from natural infection under field conditions from years 2002 to 2007

\begin{tabular}{lllllll}
\hline Susceptibility & Level $^{\mathrm{a}}$ & \multicolumn{2}{l}{ Number of cultivars $^{\mathrm{b}}$} & & \\
\cline { 3 - 7 } & & 2002 & 2003 & 2004 & 2005 & 2006 \\
\hline Resistance & $0-<1$ & 16 & 22 & 25 & 33 & 15 \\
Weak resistance & $1-<2.5$ & 11 & 17 & 18 & 21 & 12 \\
Weak susceptibility & $2.5-<4$ & 14 & 19 & 18 & 13 & 13 \\
Susceptibility & $4-5$ & 31 & 14 & 11 & 2900 \\
\hline
\end{tabular}

a Scale of Lateur and Populer (1994)

b Number of cultivars classified in each category, which was done according to the maximum symptom level showed by at least one plant among all replicates 


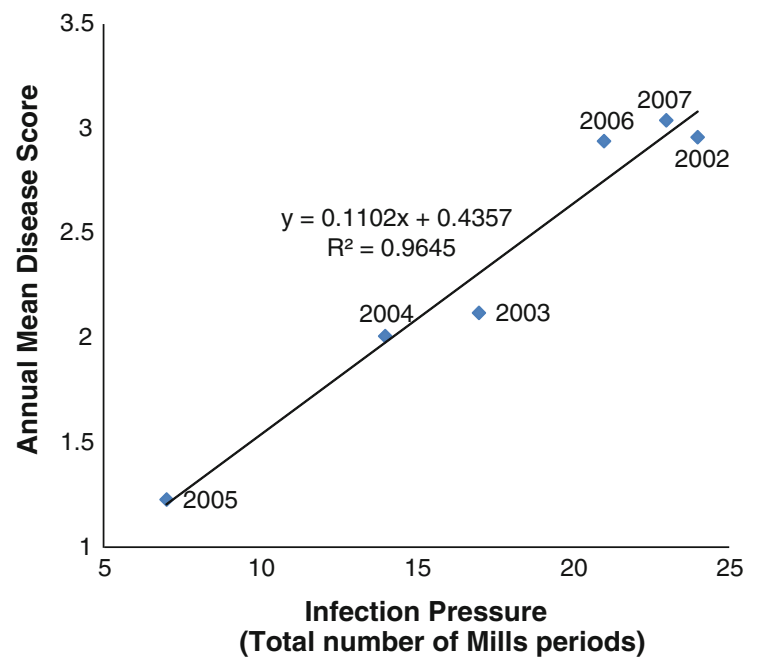

Fig. 1 Correlation between the annual mean disease score across all the accessions and total infection pressure, calculated from total number of infection periods. Each data point represents a year. Pearson correlation index was $r=0.982$ $\left(\alpha=0.01 ; r^{2}=0.965\right)$

resistant to scab showed a pronounced variation among years and was lower in those with a large number of periods of severe risk of infection (years 2002, 2006 and 2007; Fig. 1; Supplementary Table 3). These results (see Fig. 1) illustrate the pronounced effect that the environmental conditions have on the interactions between apple and $V$. inaequalis, although it is also possible that variations in the local abundance of pathogen genotypes could also influence the number of cultivars displaying resistance. Nevertheless, 14 cultivars $(1.1 .20,2.1 .1,2.1 .14,2.1 .19,2.1 .21$, 3.1.42, 3.1.47, 3.1.50, 3.1.75, 3.1.100, 3.1.109, 4.1.7, $5.1 .1,5.1 .23)$ were classified with mean scores lower than 1 , and hence as resistant to scab, for all the six evaluation years. Among these were included eight of the cultivars that showed low susceptibility to E. amylovora and resistance to inoculum UPNA99 (Table 5; Supplementary Table 1).

Taking into account the average score for the 6 years of the field experiment, there was a significant correlation between the scores in field conditions and in the glasshouse experiments according to a contingency analysis $\left(\chi^{2}=2.345 ; r^{2}=0.167 ; \alpha=0.05\right)$ (Supplementary Table 2). However, a plot of the relationship between both types of scores (data not shown) indicates that the experiments in the glasshouse tend to overestimate susceptibility.

\section{Discussion}

Host resistance is the most preferred method for the sustainable control of apple scab and fire blight, and is gaining an increasing momentum as the options for chemical control become severely limited due to new regulations and to the emergence of pathogen populations showing resistance to chemical fungicides and bactericides (Schnabel and Parisi 1997; Schnabel and Jones 2001; Norelli et al. 2003; Koller et al. 2004; Brun et al. 2008). The production of traditional cider in Spain is based on local cultivars, whose level of resistance to these diseases is unknown. In consequence, and as part of a wider project to rescue local apple germplasm suitable for the production of highquality cider (Lizar 1996; Lizar et al. 2008), we evaluated the resistance to the main apple diseases of a collection of cultivars indigenous to Spain. We have reported previously their susceptibility to fire blight (Martínez-Bilbao et al. 2009), while here we evaluated their response to apple scab.

The inoculation of 92 apple cultivars with a mixed inoculum of $V$. inaequalis revealed the existence of variability in their response to the pathogen, and allowed us to classify them into four categories of susceptibility. Nearly half of the cultivars (38 cultivars, $41.3 \%$ ) showed high levels of resistance to the pathogen, with 19 cultivars being classified into the resistance class, suggesting that this germplasm collection is a good source of genetic determinants for resistance to apple scab. In all cultivars showing resistance, the pathogen spores could germinate and penetrate the host, but further growth was halted and no sporulation was detected. This indicates that resistance is not due to the inability of the pathogen to breach the external barriers of the plant host, but rather to the existence of effective defence mechanisms or to the lack of essential factors in the host to sustain the growth of the parasite. Nevertheless, further studies would be necessary to clarify the molecular mechanisms responsible for the different resistance phenotypes observed in this study.

We have previously assessed the susceptibility of these 92 apple cultivars to fire blight (Martínez-Bilbao et al. 2009), which is one of the three most important diseases of apple in Spain. Comparison of these data with those obtained in the present work indicated that resistance to apple scab and fire blight was not correlated as a contingency analysis $\left(\chi^{2}=20.457\right.$; 
Table 5 Evaluation of susceptibility to apple scab in field conditions of ten apple cultivars previously classified as having low susceptibility to fire blight and resistance to scab inoculum UPNA99 ${ }^{\mathrm{a}}$

\begin{tabular}{|c|c|c|c|c|c|c|c|c|}
\hline \multirow[t]{2}{*}{ Cultivar $^{\mathrm{b}}$} & \multicolumn{8}{|c|}{ Susceptibility } \\
\hline & 2002 & 2003 & 2004 & 2005 & 2006 & 2007 & Average & $\overline{\text { Class }^{\mathrm{c}}}$ \\
\hline 1.1 .9 & $1.2 \pm 0.4$ & $0.7 \pm 0.3$ & $0.5 \pm 0.2$ & $0.3 \pm 0.1$ & $1.3 \pm 0.3$ & $1.6 \pm 0.4$ & $0.9 \pm 0.2$ & WR \\
\hline 1.1.20 & $0.3 \pm 0.2$ & $0.3 \pm 0.1$ & $0.0 \pm 0$ & $0.0 \pm 0$ & $0.5 \pm 0.2$ & $0.7 \pm 0.2$ & $0.3 \pm 0.1$ & $\mathrm{R}$ \\
\hline 2.1.1 & $0.8 \pm 0.3$ & $0.4 \pm 0.1$ & $0.3 \pm 0.1$ & $0.0 \pm 0$ & $0.9 \pm 0.3$ & $1.0 \pm 0.2$ & $0.6 \pm 0.2$ & $\mathrm{R}$ \\
\hline 2.1 .14 & $0.0 \pm 0$ & $0.3 \pm 0.1$ & $0.4 \pm 0.1$ & $0.0 \pm 0$ & $0.2 \pm 0.1$ & $0.3 \pm 0.1$ & $0.2 \pm 0.1$ & $\mathrm{R}$ \\
\hline 2.1 .21 & $0.1 \pm 0.2$ & $0.3 \pm 0.1$ & $0.0 \pm 0$ & $0.0 \pm 0$ & $0.3 \pm 0.2$ & $0.3 \pm 0.2$ & $0.2 \pm 0.1$ & $\mathrm{R}$ \\
\hline 3.1 .50 & $0.5 \pm 0.2$ & $0.0 \pm 0$ & $0.0 \pm 0$ & $0.0 \pm 0$ & $0.5 \pm 0.2$ & $0.4 \pm 0.2$ & $0.2 \pm 0.1$ & $\mathrm{R}$ \\
\hline 3.1 .75 & $0.3 \pm 0.1$ & $0.0 \pm 0$ & $0.0 \pm 0$ & $0.0 \pm 0$ & $0.4 \pm 0.2$ & $0.6 \pm 0.3$ & $0.2 \pm 0.1$ & $\mathrm{R}$ \\
\hline 3.1 .80 & $3.1 \pm 0.9$ & $1.3 \pm 0.3$ & $0.9 \pm 0.2$ & $0.5 \pm 0.2$ & $2.3 \pm 0.3$ & $2.1 \pm 0.5$ & $1.7 \pm 0.4$ & WS \\
\hline 3.1 .100 & $0.4 \pm 0.2$ & $0.0 \pm 0.0$ & $0.0 \pm 0$ & $0.0 \pm 0$ & $0.7 \pm 0.3$ & $0.8 \pm 0.2$ & $0.3 \pm 0.2$ & $\mathrm{R}$ \\
\hline 5.1 .23 & $0.2 \pm 0.1$ & $0.0 \pm 0.0$ & $0.0 \pm 0$ & $0.0 \pm 0$ & $0.3 \pm 0.1$ & $0.2 \pm 0.1$ & $0.1 \pm 0.1$ & $\mathrm{R}$ \\
\hline Morro liebre $^{\mathrm{d}}$ & $4.2 \pm 0.5$ & $2.5 \pm 0.3$ & $2.5 \pm 0.5$ & $1.8 \pm 0.4$ & $4.2 \pm 0.3$ & $4.4 \pm 0.5$ & $3.3 \pm 0.5$ & $\mathrm{~S}$ \\
\hline
\end{tabular}

${ }^{a}$ Evaluated using the scale of Lateur and Populer (1994), which varies between 0 (resistance) and 5 (susceptibility); see Table 4. Values are the average of five plants per cultivar \pm standard deviation

b The first susceptibility assessment was made when plants were 3 years old

${ }^{c}$ R (resistance), WR (weak resistance), WS (weak susceptibility), S (susceptibility)

d Cultivar susceptible to mixed inoculum UPNA99

$\left.r^{2}=0.016 ; \alpha=0.05\right)$ suggested that they are independently inherited. Nevertheless, 22 of the cultivars showing low susceptibility to fire blight were either resistant (12 cultivars) or weakly resistant (10 cultivars) to the mixed inoculum UPNA99 (Table 1).

Of considerable interest is the fact that 12 of the cultivars were classified in the categories for highest resistance to both fire blight and apple scab using artificial inoculations. These 12 cultivars also showed varying levels of resistance to artificial inoculation with monoconidial isolates of races $(1),(1,6)$ and $(6$, 7,13 ), with only a few showing susceptibility to these reference isolates. Intriguingly, even the cultivars showing susceptibility to the race (6) isolate displayed resistance to the mixed inoculum UPNA99, while they should predictably behave as susceptible, because this inoculum contains race (6). We do not have a satisfactory explanation for this behaviour, but it is conceivably influenced by different factors, such as the occurrence of pathogenic diversity among isolates classified as race (6); the presence of other races in the mixed inoculum that could trigger an effective defence response in the host, particularly if race (6) was in a low proportion; the existence of a level of polygenic resistance in these cultivars contributing to disease avoidance, or the fact that mixtures of cultivars effectively reduce the incidence and severity of apple scab (Didelot et al. 2007). The appearance and widespread occurrence of race (6) pathotypes, which overcome the resistance conferred by gene Rvi6, has prompted the search for new sources of durable resistance and the necessity to combine different resistance genes in the same genotype (pyramiding). The resistance behaviour of these 12 cultivars to a mixed inoculum and to races $(6)$ and $(6,7,13)$ isolates has therefore a considerable practical interest.

The resistance scores estimated from glasshouse inoculation experiments and the behaviour of cultivars to natural infections in field conditions were significantly correlated. There are only a few other studies that compared susceptibility data from plants in controlled conditions and in the field, and either they did (Heaton et al. 1995) or they did not (MacHardy 1996) find a significant correlation between both conditions. Nevertheless, the glasshouse inoculation experiments tended to overestimate the cultivar susceptibility to apple scab. MacHardy (1996) reports that it is common that apple seedlings show a higher susceptibility in response to inoculation under greenhouse conditions than when planted outdoors and subjected to natural inoculum, and that environmental conditions such as inoculum concentration, 
photoperiod and light intensity could also alter the plant susceptibility. Although this indicates the need to evaluate the resistance to apple scab of candidate apple cultivars in the field, the selection of cultivars with low susceptibility to scab under controlled conditions might help to select those with the highest background of minor genes for resistance (MacHardy 1996).

Among the 14 cultivars that showed resistance to apple scab in field conditions were eight cultivars with high resistance to fire blight (cultivars 1.1.20, 2.1.1, 2.1.14, 2.1.21, 3.1.50, 3.1.75, 3.1.100, and 5.1.23). These cultivars were classified as resistant to apple scab every year during a 6 years evaluation in the field, in spite of the occurrence each year of one to six Mills periods of severe risk of infection with the concomitant appearance of severe symptoms of apple scab in a number of other cultivars. From an occasional sporulating lesion from cultivar 2.1.1 in 2003, we obtained a monosporic isolate of $V$. inaequalis that was classified as race $(6,7)$ (Martínez-Bilbao and Murillo 2005). Noticeably, cultivars 2.1.1, 2.1.14 and 5.1.23, which were classified as susceptible to race $(6,7,13)$, showed a very low level of infection throughout the evaluation period, in spite of the demonstrated presence of races $(6)$ and $(6,7)$ in the evaluation orchard, which might be interpreted as we discussed above. Another of the cultivars tested, cultivar 1.1.9, was classified as either resistant or weakly resistant. Since the phenotype of weak resistance was only observed during the years with higher risk of infection, this cultivar is also of interest for the management of apple scab using genetic resistance.

In conclusion, we identified eight apple cultivars with low susceptibility to fire blight and resistance to apple scab, both to a mixed inoculum in the glasshouse and in the field. These cultivars show diverse combinations of resistance to races $(1,6)$ and $(6,7,13)$ of $V$. inaequalis. The availability of these cultivars and others showing resistance to apple scab is highly relevant for the cider industry through their use in integrated production and facilitating the production of organic cider. Additionally, these cultivars could be incorporated into appropriate breeding programs, commencing with investigations on the genetic basis of their resistance.

Acknowledgments This research was supported by grant PA123 from the Departamento de Educación y Cultura, Gobierno de Navarra. We are indebted to two anonymous reviewers for their insightful comments and their helpful suggestions. We are very grateful to E. Dapena for his generous gift of the differential apple clones, to Benigno Lizar, Miguel Esparza, Javier Sanz, and other members of the Instituto Técnico de Gestión Agrícola for plant material and useful advice, and to Bruno Le Cam for providing the strains corresponding to races $(1),(1,6)$ and $(6,7,13)$ of $V$. inaequalis. We gratefully acknowledge Theresa $\mathrm{H}$. Osinga for critical reading of the manuscript and help with the English language.

Open Access This article is distributed under the terms of the Creative Commons Attribution License which permits any use, distribution, and reproduction in any medium, provided the original author(s) and the source are credited.

\section{References}

Belfanti E, Silfverberg-Dilworth E, Tartarini S, Patocchi A, Máximo B, Zhu J, Vinatzer BA, Gianfranceschi L, Gessler C, Sansavini S (2004) The HcrVf2 gene from a wild apple confers scab resistance to transgenic cultivated variety. Proc Natl Acad Sci USA 101:886-890. doi:10.1073/ pnas.0304808101

Bénaouf G, Parisi L (2000) Genetics of host-pathogen relationships between Venturia inaequalis races 6 and 7 and Malus species. Phytopathology 90:236-242. doi:10.1094/ PHYTO.2000.90.3.236

Bowen JK, Mesarich CH, Bus VGM, Beresford RM, Plummer KM, Templeton MD (2011) Venturia inaequalis: the causal agent of apple scab. Mol Plant Pathol 12:105-122. doi:10.1111/j.1364-3703.2010.00656.x

Brun L, Didelot F, Parisi L (2008) Effects of apple cultivar susceptibility to Venturia inaequalis on scab epidemics in apple orchards. Crop Prot 27:1009-1019. doi:10.1016/ j.cropro.2007.12.009

Bus VGM, Laurens F, Van de Weg WE, Rusholme RL, Rikkerink E, Gardiner S, Bassett HCM, Kodde LP, Plummer KM (2005) The Vh8 locus of a new gene-for-gene interaction between Venturia inaequalis and the wild apple Malus sieversii is closely linked to Vh2 locus in Malus pumila. New Phytol 166:1035-1049. doi:10.1111/j.14698137.2005.01395.x

Bus VGM, Rikkerink EHA, Caffier V, Durel CE, Plummers KM (2011) Revision of nomenclature of the differential hostpathogen interactions of Venturia inaequalis and Malus. Annu Rev Phytopathol 49:391-413. doi:10.1146/annurevphyto-072910-095339

Cavanna M, Marinoni DT, Bounous G, Botta R (2008) Genetic diversity in ancient apple germplasm from Northwest Italy. J Hortic Sci Biotechnol 83:549-554

Chevalier M, Lespinasse Y (1991) Resistance of the apple tree (Malus $\times$ domestica Borkh.) to Venturia inaequalis (Cke.) Wint. Histological and ultrastructural-study of the pinpoint symptom. C R Acad Sci III 312:117-124

Chevalier M, Lespinasse Y, Renaudin S (1991) A microscopic study of the different classes of symptoms coded by the $V f$ gene in apple for resistance to scab (Venturia inaequalis). Plant Pathol 40:249-256. doi:10.1111/j.1365-3059.1991. tb02374.x 
Didelot F, Brun L, Parisi L (2007) Effects of cultivar mixtures on scab control in apple orchards. Plant Pathol 56:1014-1022. doi:10.1111/j.1365-3059.2007.01695.x

Fischer M, Dunemann F (2000) Search for polygenic scab and mildew resistance in apple cultivars cultivated at the fruit genbank Dresden-Pillnitz. Acta Hortic 538:71-77

Gessler C, Patocchi A, Sansavini S, Tartarini S, Gianfranceschi L (2006) Venturia inaequalis resistance in apple. Crit Rev Plant Sci 25:473-503. doi:10.1080/07352680601015975

Hartman JR, Paulin JP, Parisi L, Thomson S (2000) INRA and apple disease research in the Loire Valley Region of France. Plant Dis 84:928-936. doi:10.1094/PDIS.2000. 84.9.928

Heaton JB, Dullahide SR, Tancred SJ, Zeppa AG, McWaters AD (1995) Comparison of orchard and glasshouse tests in screening of apple breeding progeny for resistance to Venturia inaequalis in Queensland from 1985 to 1994. Australas Plant Pathol 24:243-248. doi:10.1071/ APP9950243

Hough LF, Shay JR, Dayton DF (1953) Apple scab resistance from Malus floribunda. Proc Am Soc Hortic Sci 62: 341-347

Hough LF, Williams EB, Dayton DF, Shay JR, Bailey CH, Mowry CH, Janick J, Emerson FH (1970) Progress and problems in breeding apples for scab resistance. In: Proceedings of the Angers fruit breeding symposium. INRA, Versailles, pp 217-230

Itoiz R, Royo JB (2003) Isoenzymatic variability in an apple germplasm bank. Genet Resour Crop Evol 50:391-400. doi:10.1023/A:1023970926516

Keitt GV, Palmiter DH (1938) Heterothallism and variability in Venturia inaequalis. Am J Bot 25:338-345. doi:10.2307/ 2436758

Koller W, Parker DM, Turechek WW, Avila-Adame C, Cronshaw K (2004) A two-phase resistance of Venturia inaequalis populations to the Qol fungicides kresoxim-methyl and tryfloxystrobin. Plant Dis 88:537-544. doi:10.1094/ PDIS.2004.88.5.537

Lacis G, Kota I, Ikase L, Rungis D (2011) Molecular characterization of the Latvian apple (Malus) genetic resource collection based on SSR markers and scab resistance gene Vf analysis. Plant Genet Resour 9:189-192. doi:10.1017/ s1479262111000384

Lateur M, Populer C (1994) Screening fruit tree geneticresources in Belgium for disease resistance and other desirable characters. Euphytica 77:147-153. doi:10.1007/ BF02551478

Lespinasse Y, Durel CE, Laurens F, Parisi L (2000) A European project: D.A.R.E.-Durable Apple Resistance in Europe (Fair5 CT97-3898), durable resistance of apple to scab and powdery-mildew: one step more towards an environmental friendly orchard. Acta Hortic 538:197-200

Lizar B (1996) Selección del manzano autóctono de Navarra. Navar Agrar 99:19-30

Lizar B, Suberviola J, Arina D (2008) Selección de variedades de manzano autóctono de Navarra para la elaboración de sidra natural. Navar Agrar 168:25-32

Lodhi M, Guang-Ning Y, Norman F, Bruce I (1994) A simple and efficient method for DNA extraction from grapevine cultivars, Vitis species and Ampelopsis. Plant Mol Biol Rep 12:6-13. doi:10.1007/BF02668658
Ma ZH, Michailides TJ (2005) Advances in understanding molecular mechanisms of fungicide resistance and molecular detection of resistant genotypes in phytopathogenic fungi. Crop Prot 24:853-863. doi:10.1016/j.cropro. 2005.01.011

MacHardy WE (1996) Apple scab. Biology, epidemiology and management. APS Press, St. Paul

MacHardy WE, Gadoury DM (1989) A revision of Mills criteria for predicting apple scab infection periods. Phytopathology 79:304-310. doi:10.1094/Phyto-79-304

Martínez-Bilbao A, Murillo J (2005) Six races of Venturia inaequalis are found causing apple scab in Spain. Plant Dis 89:908. doi:10.1094/PD-89-0908A

Martínez-Bilbao A, Ortiz-Barredo A, Montesinos E, Murillo J (2009) Evaluation of a cider apple germplasm collection of local cultivars from Spain for resistance to fire blight (Erwinia amylovora) using a combination of inoculation assays on leaves and shoots. HortScience 44:1223-1227

Mills WD, LaPlante AA (1951) Diseases and insects in the orchard. Cornell Ext Bull 711:100

Nicholson RI, Kuc J, Williams EB (1972) Histochemical demonstration of transitory esterase activity in Venturia inaequalis. Phytopathology 62:1242-1247. doi:10.1094/ Phyto-62-1242

Norelli JL, Jones AL, Aldwinckle HS (2003) Fire blight management in the twenty-first century-using new technologies that enhance host resistance in apple. Plant Dis 87:756-765. doi:10.1094/PDIS.2003.87.7.756

Ortega F, Steiner U, Dehne HW (1998) Induced resistance to apple scab: microscopic studies on the infection cycle of Venturia inaequalis (Cke.) Wint. J Phytopathol 146:399-405. doi:10.1111/j.1439-0434.1998.tb04771.x

Parisi L, Lespinasse Y, Guillaumes J, Kruger J (1993) A new race of Venturia inaequalis virulent to apples with resistance due to the Vf gene. Phytopathology 83:533-537. doi:10.1094/Phyto-83-533

Parisi L, Fouillet V, Schouten HJ, Groenwold R, Laurens F, Didelot F, Evans KM, Fischer C, Gennari F, Kemp H, Lateur M, Patocchi A, Thissen J, Tsipouridis C (2004) Variability of the pathogenicity of Venturia inaequalis in Europe. Acta Hortic 663:107-113

Pereira-Lorenzo S, Ramos-Cabrer AM, Diaz-Hernandez MB (2007) Evaluation of genetic identity and variation of local apple cultivars (Malus $\times$ domestica Borkh.) from Spain using microsatellite markers. Genet Resour Crop Evol 54:405-420. doi:10.1007/s10722-006-0003-7

Quello KL, Chapman KS, Beckerman JL (2010) In situ detection of benzimidazole resistance in field isolates of Venturia inaequalis in Indiana. Plant Dis 94:744-750. doi:10.1094/pdis-94-6-0744

Roberts AL, Crute IR (1994) Improved procedures for the in vivo and in vitro production of conidial inoculum of Venturia species of pome fruit. Ann Appl Biol 125:607-613. doi:10.1111/j.1744-7348.1994.tb04997.x

Rop O, Jurikova T, Sochor J, Mlcek J, Kramarova D (2011) Antioxidant capacity, scavenging radical activity and selected chemical composition of native apple cultivars from Central Europe. J Food Qual 34:187-194. doi:10.1111/j.1745-4557.2011.00387.x

Schnabel G, Jones AL (2001) The 14 alpha-demethylase (CYP51A1) gene is overexpressed in Venturia inaequalis 
strains resistant to myclobutanil. Phytopathology 91: 102-110. doi:10.1094/PHYTO.2001.91.1.102

Schnabel G, Parisi L (1997) Sensitivity of Venturia inaequalis to five DMI fungicides, including the new triazole fluquinconazole, and to pyrimethanil. Z Pflanzenk Pflanz 104: $36-46$

Szkolnik M (1986) Preparation of inoculum for brown rot of stone fruits and apple scab. In: Hickey KD (ed) Methods for evaluating pesticides for control of plant pathogens. APS Press, St. Paul, pp 71-72
Tiirmaa K, Univer T, Univer N (2009) The evaluation of scab resistant apple cultivars in Estonia. Agron Res 7:528-531 Vinatzer BA, Patocchi A, Gianfranceschi L, Tartarini S, Zhang HB, Gessler C, Sansavini S (2001) Apple contains receptor-like genes homologous to the Cladosporium fulvum resistance gene family of tomato with a cluster of genes cosegregating with Vf apple scab resistance. Mol PlantMicrobe Interact 14:508-515. doi:10.1094/MPMI.2001. 14.4.508 